\title{
Digestibility of whole grain crop silages determined by different methods ${ }^{*}$
}

\section{P. Micek ', Z.M. Kowalski', F. Borowiec ${ }^{1}$ and J.A. Shelford ${ }^{2}$}

\author{
'Department of Animal Nutrition, Cracow' Agricultural University \\ Al. Mickiewicza 24/28, 30-059 Krakow, Poland \\ 'Faculty of Agricultural Sciences. University of British Columbia \\ 248-2387 Main Mall, Vancouver; BC, V6T IZ4, Canada
}

(Received 29 September 2000; revised version 19 July 2001; accepted 6 November 2001)

\begin{abstract}
Digestibility of whole grain crop silages was estimated by an in vivo method and by three different in vitro techniques: in situ nylon bag, in vitro true digestibility (IVTD) and in vitro gas production (GP). The silages were made of oat (Avena sativa, var. Senator) and triticale (var. Bogo), cut at three stages of maturity: heading (H), milk (M) and milk-dough (MD). Starch contents ( $\mathrm{g} \mathrm{kg}^{-1} \mathrm{DM}$ ) in oat silages were 13,110 and 130 and in triticale 7,78 and 147 , for $\mathrm{H}, \mathrm{M}$ and MD stages of maturity, respectively. For the same silages and stages of maturity, NDF contents ( $\mathrm{g} \mathrm{kg}^{-1} \mathrm{DM}$ ) were $471,506,483$ and $517,551,499$, respcctivcly.

The silages made at heading stage had the highest in vivo DM digestibility and in situ DM effective rumen degradability (ERD). In vivo DM digestibility was significantly correlated with the starch content in the silages. There was no significant correlation between ERD and starch and NDF contents but significant correlations between starch content and $A, B$ and $C$ parameters of $D M$ degradability were found $(r>0.90 ; P<0.05)$. Regardless of the species, silages made at $M$ and MD stages had a lower IVTD than $H$ silages. There was no significant correlation between IVTD and starch and NDF contents. Total gas production (TGP) as well as GP rate constant pointed at MD silages, especially oat, as the most digestible. There was no significant correlation between TGP and starch and NDF contents. However, a significant correlation $(P<0.05)$ was found between GP rate constant and starch content. Among the methods compared, the highest correlation with in vivo DM digestibility was found for fractions A and B (in situ method), IVTD 48 and GP rate constant (gas production technique).
\end{abstract}

- Supportcd by the State Committee for Scientific Research, Grant No P06E 00218 
KEY WORDS: whole grain crop silagc, stage of maturity, starch, digestibility, in situ, in vitro, gas production technique

\section{INTRODUCTION}

The efficiency of ruminant production is largely limited by forage quality, in which the most important is rumen digestibility. Low digestibility is mainly reflected in low voluntary intake and finally in low energy supply (Van Soest, 1994). Determination of digestibility by the standard in vivo methods is time-consuming, laborious, expensive, and requires a large quantity of experimental feed. Therefore, many attempts have been directed towards the development of new methods that could satisfactorily predict forage intake and digestibility (Stern et al., 1997; Jones and Theodorou, 2000). New methods which have been the most often studied are in situ and in vitro, including gas production technique (Deaville et al., 1998). To reduce the cost of analysis and to increase its precision, new equipment has also become available. For example, the in vitro method invented by Van Soest et al. (1966) can now be performed using filter bags and a Daisy Incubator (IVTD, Ankom Co, Fairport, NY). However, it was shown in the study of Wilman and Adesogan (2000) that IVTD had a higher standard error and cocfficient of variation than conventional tube methods. Similarly, based on the principles described by Menke et al. (1979), automated gas production equipment gives the opportunity for simultaneous analysis of numbers of samples (Schofield and Pell, 1995; Williams, 2000).

The so-called "altemative" methods of the estimation of digestibility need to be standardized with the in vivo method, particularly due to a significant effect of chemical and physical characteristics of samples (Stern et al., 1997). One of these characteristics is the origin of starch and its content in the feedstuffs. Previously conducted studies have shown a considerable influence of starch on the digestibility of feedstuffs determined by different methods (Cerneau and Michalet-Doreau, 1991; Opatpatanakit et al., 1994) as well as on the accuracy of predicting ruminal nutrient degradation (Mills et al., 1999).

The most notable changes in the chemical composition of whole grain crops due to advancing maturity are in dry matter (DM), non-fibre carbohydrates (NFC), starch and crude fibre contents (Mannerkorpi and Brandt, 1995). Thus, whole grain crop silages made of plants cut at different stage of maturity may be used as model samples for determining the influence of starch content on roughage digestibility assessed by different methods.

The aim of the present study was to determine the effect of stage of maturity of oat and triticale on chemical composition as well as on digestibility of whole grain oat or triticale silages determined by different methods: in vivo, in situ, in vitro and gas production technique. 


\section{MATERIAL AND METHODS}

\section{Design and treatments}

Whole grain crop silages were made of oat (Avena sativa, var. Senator) and triticale (var. Bogo), cut at three stages of maturity: heading (H), milk (M) and milk-dough (MD). The plants were harvested in 1998, on June 19, July 13 and July 18 (oat) and May 28, June 19 and June 30 (triticale), respectively. After the cut, the plants were chopped and ensiled with a microbial inoculant additive (Microsil, $10 \mathrm{~g} / \mathrm{T}$ fresh forage) in $100 \mathrm{l}$ plastic containers $(9$ containers for each forage, 54 containers in total). After 4 months, representative samples were taken from 3 sites of each container. The samples were then pooled together by containers and frozen at $-20^{\circ} \mathrm{C}$ until the chemical analysis. Chemical analyses were made separately for each container. For the same crop and cut, dried samples $\left(45^{\circ} \mathrm{C}, 48 \mathrm{~h}\right)$ from each container were then pooled together for digestibility trials.

In vivo total tract dry matter digestibility of silages was determined using 12 wethers allocated randomly into 3 groups. The animals were kept in metabolic cages and fed experimental silages (plus mineral mixture, $20 \mathrm{~g} \mathrm{~d}^{-1}$ head) twice a day, at a dose close to maintenance level. At the same time 3 silages of the same species were studied. The 7-day collection period followed the adaptation period that lasted 14 days. Representative samples of feeds, refusals and faeces were kept frozen at $-20^{\circ} \mathrm{C}$ until chemical analysis.

In situ rumen dry matter degradability (ISNB) was determined by the method of Michalet-Doreau et al. (1987). Measurements were carried out using three ruminally cannulated Holstein bulls weighing $390 \pm 30 \mathrm{~kg}$. The animals were given $5.6 \mathrm{~kg} \mathrm{~d}^{-1}$ of meadow hay and $2.3 \mathrm{~kg} \mathrm{~d}^{-1}$ of concentrate mixture (\%: barley, 50 ; wheat, 10; wheat bran, 28; soyabean meal, 10; mineral mixture, 2). The diet contained $170 \mathrm{~g} \mathrm{~kg}^{-1} \mathrm{DM}$ of crude protein and was balanced to keep the forage to concentrate ratio at 70:30. Approximately $3 \mathrm{~g}$ of samples dried and ground to pass through a $1.5 \mathrm{~mm}$ sieve screen were placed into nylon bags (Ankom Co, Fairport, NY; pore size $53 \mathrm{~mm}$ diameter, internal dimension $5 \times 10 \mathrm{~cm}$ ), yielding a ratio of sample mass per bag area of $27 \mathrm{mg} \mathrm{cm}^{-2}$. Bags were introduced in the rumen at the same time just before the morning feeding and pulled out at different times. Incubations ware carried out at $2,4,8,16,24,48$ and $72 \mathrm{~h}$. Additionally incubation for $0 \mathrm{~h}$ was done to estimate washing losses from bags. Nine measurements (three replications for each of three steers) were made for each incubation time. After removal, bags were rinsed thoroughly with cold water and then washed in a washing machine, and dried to the constant weight. The effective rumen degradability (ERD) of dry matter and the degradability rate constants (A, B, C) were calculated according to Ørskov and McDonald (1979) 
at a ruminal outflow $(\mathrm{k})$ of $0.06 \mathrm{~h}^{-1}$, which is the value accepted for high yielding dairy cows. The data for one animal was then pooled before statistical analysis.

In vitro true digestibility (IVTD) was estimated in a Daisy Incubator (Ankom Co, Fairport, NY) based on the Van Soest et al. (1966) tube procedure. The dried and ground (1.5 $\mathrm{mm}$ as above) samples were placed in filter bags made from polyester/polyethylene extruded filaments $(50 \times 55 \mathrm{~mm}$ exterior size $)$. The bags ( 3 jars $\times 3$ replications) were then incubated in the incubation jar in buffering ruminal fluid for 8,24 and $48 \mathrm{~h}$. According to Ankom's recommendation, $0.25 \mathrm{~g}$ of sample per bag were weighed for 8 and $24 \mathrm{~h}$ incubations and $0.5 \mathrm{~g}$ for $48 \mathrm{~h}$ incubation. Rumen fluid was collected by rumen cannula from two dry HolsteinFriesian cows fed with $5 \mathrm{~kg} \mathrm{~d}^{-1}$ of meadow hay and $2 \mathrm{~kg} \mathrm{~d}^{-1}$ of barley grain with mineral mixture supplementation. The diet contained $140 \mathrm{~g} \mathrm{~kg}^{-1} \mathrm{DM}$ of crude protein. The rumen fluid was collected directly before determinations. After incubation, the jars were drained and the bags rinsed thoroughly with cold tap water. The bags with residues were boiled for $75 \mathrm{~min}$ in neutral detergent solution (Ankom ${ }^{220}$ apparatus). After the solution was removed, $2000 \mathrm{ml}$ of hot (90$\left.100^{\circ} \mathrm{C}\right) \mathrm{H}_{2} \mathrm{O}$ and $4.0 \mathrm{ml}$ of $\alpha$-amylase were used in the first and second rinses of bags. The bags were then dried and weighed. Use of the neutral detergent solution and $\alpha$-amylase (in samples containing starch) is an integrated step of the IVTD method. Since digestibility results obtained from this method depend mainly on the extent of fermentation of samples in the buffered ruminal fluid, it is assumed that it reflects potential rumen digestibility and can be compared with other methods used in the experiment.

Potential digestibility of silage dry matter was also estimated using semiautomated gas production technique (GP) (Pell and Schofield, 1993), which was based on the original Menke and Steingass procedure (1988). The rumen fluid from two dry Holstein-Friesian cows was collected similarly as above. The amount of gas produced in an individual flask (4 repetitions for each sample) containing $0.15 \mathrm{~g}$ of dried and ground $(1.5 \mathrm{~mm})$ sample and buffered ruminal fluid was measured every $10 \mathrm{~min}$ over $24 \mathrm{~h}$ by computer-interfaced pressure sensors. The $24 \mathrm{~h}$ incubation time was chosen as suggested by Menke et al. (1979) and Menke and Steingass (1988), although other authors have used longer incubation. The $24 \mathrm{~h}$ incubation time in this project was also chosen considering the high fermentation rate of whole crop silage organic matter in the rumen. For each fermentation run, three blank samples containing only buffered ruminal fluid were used. Blank sample fermentation readings were then considered in the calculations of the total gas produced (TGP). TGP as well as GP rate constants were calculated using the exponential Ørskov and McDonald (1979) equation, modified for the LAG time (Beuvink and Kogut, 1993). 
Analytical procedures and measurements

Dry matter content of silages was determined by the toluene method (Dewar and McDonald, 1961). Chemical composition of silages, refusals, faeces and in situ and in vitro residuals was determined on dried $\left(45^{\circ} \mathrm{C}, 48 \mathrm{~h}\right)$ and ground (to pass through a $1.5 \mathrm{~mm}$ screen) samples using standard methods (AOAC, 1995). Water-soluble carbohydrates (WSC) were determined by the colorimetric method of Deriaz (1961), starch content by the method of Faisant et al. (1995) and NDF, ADF and ADL by the method of Goering and Van Soest (1970).

\section{Statistical analysis}

The data, separately for oat and triticale, were subjected to one-way analysis of variance using the GLM procedure of SAS (1995). The model employed for statistical analysis was as follows: Yijk $=\mu+\mathrm{Ti}+\mathrm{Rj}+\mathrm{Eij}$, where: $\mu=$ general mean, $\mathrm{Ti}=$ treatment effect, $\mathrm{Rj}=$ repetition effect $($ animal $($ ISNB) or jar (IVTD) or channel $(\mathrm{GP}))$, Eij = experimental error. In each analysis, the individual means were separated by the Student-Newman-Keuls test (SAS, 1995). Differences were considered to be significant at $\mathrm{P}<0.05$. Relationships between parameters of digestibility, determined by different methods, were tested by correlation coefficients using REG procedure of SAS (1995).

\section{RESULTS AND DISCUSSION}

The chemical composition of silages is presented in Table 1. Aging of plants increased dry matter and starch contents, which was accompanied by a decrease in protein content. The same tendencies as related to stage of maturity were observed by Mannerkorpi and Brandt (1995) on barley plants and seem to be true for all cereal species. Irrespective of the species, $M$ and MD silages had higher content of ADL than $H$ silages $(\mathrm{P}<0.05)$. On the other hand, NDF and ADF contents were slightly increased in $\mathrm{M}$ silages and then decreased in MD ones.

Regardless of the plant species, the highest total tract in vivo DM digestibility was shown for silages made at the heading stage of maturity $(\mathrm{P}<0.05$; Table 2$)$. It is worth noting that aging of oat to MD stage did not further decrease DM digestibility, compared to $\mathrm{M}$ stage. Also Borowiec et al. (1998) in in vivo studies conducted on whole crop barley silages showed similar tendencies as related to stage of maturity. In vivo DM digestibility in the present studies was negatively correlated with a starch content and was not influenced by the NDF content (Table 3). Prolonging plant growth is usually accompanied with an increase in fibre content (Van Soest, 1994). However, in this study an increase in NDF content was "dilu- 
TABLE 1

Chemical composition of silages, $\mathrm{g} \mathrm{kg}^{-1} \mathrm{DM}$

\begin{tabular}{|c|c|c|c|c|c|c|}
\hline \multirow{2}{*}{ Stage of maturity } & \multicolumn{3}{|c|}{ Oat } & \multicolumn{3}{|c|}{ Triticale } \\
\hline & $\mathrm{H}$ & M & MD & $\mathrm{H}$ & M & MD \\
\hline Dry matter, $\mathrm{g} \mathrm{kg}^{-1}$ & 198 & 266 & 296 & 170 & 293 & 334 \\
\hline Organic matter & 916 & 928 & 927 & 918 & 933 & 937 \\
\hline Crude protein & 96 & 69 & 69 & 94 & 75 & 60 \\
\hline Ether extract & 73 & 62 & 52 & 49 & 38 & 27 \\
\hline Crude fibre & 243 & 265 & 264 & 284 & 299 & 278 \\
\hline $\mathrm{NFC}^{2}$ & 504 & 532 & 542 & 491 & 521 & 572 \\
\hline $\mathrm{WSC}^{3}$ & 13 & 23 & 20 & 12 & 96 & 39 \\
\hline Starch & 13 & 110 & 130 & 7 & 78 & 147 \\
\hline NDF & 471 & 506 & 483 & 517 & 551 & 499 \\
\hline $\mathrm{ADF}$ & 299 & 336 & 311 & 337 & 357 & 342 \\
\hline ADL & 25 & 48 & 47 & 30 & 57 & 54 \\
\hline
\end{tabular}

' $\mathrm{H}$ - heading; $\mathrm{M}$ - milk stage; $\mathrm{MD}$ - milk-dough stage

2 non-fibre carbohydrates

${ }^{3}$ water-soluble carbohydrates

ted" by the increase in starch content, which was probably the reason for the lack of influence of fibre on digestibility. The origin of the fibre should also be considered here, because of the changes not only in the concentration of NDF but also in its composition, which take place when the plant matures. Increases in highly digestible starch content in M and MD silages (Micek et al., 2001) with advancing maturity of plants balanced a possible decrease in DM digestibility due to changes in cell wall structure.

Oat and triticale silages made at heading stage of maturity had the highest ERD of DM (Table 2), probably due to the lowest NDF and ADL contents. Fast lignification of the plant cell wall between $\mathrm{H}$ and $\mathrm{M}$ stage of growth (Table 1) might cause a decrease in the ERD of $M$ silages. As mentioned above, although the plant still matures, an increase in NFC content, particularly starch, in MD silages, when compared to $\mathrm{M}$ silages, could dilute this lignification effect. As a result the ERDs of MD silages were significantly increased over $\mathrm{M}$ ones. Thus, it is likely that the difference in ERD between $\mathrm{H}$ and $\mathrm{M}$ silages was influenced mainly by the fibre content whereas the difference between $\mathrm{M}$ and MD silages was more affected by the starch content. However, the overall correlation between ERD and starch or NDF contents was not significant (Table 3 ).

For 0,2 and $4 \mathrm{~h}$ of incubation (Table 2), MD silages had the highest DM disappearance, which was in line with the highest value of fraction A. On the other hand, for incubations lasting for a longer time, the highest disappearance was shown for $\mathrm{H}$ silages. They also had the highest proportion of fraction $\mathrm{B}$, and the highest 
rate of digestibility (fraction $\mathrm{C}$ ). The reasons for such tendencies could be the starch and fibre contents in the sample. If the MD silages contained the highest amount of starch and the lowest of fibre and additionally the starch of these forages is highly and rapidly degraded in the rumen (Micek et al., 2001), it is clear that DM degradability of MD silages at short periods of incubation was the highest. When the starch has already been degraded (after 8-16 h) (Micek et al., 2001), it is possible that the DM degradability at longer incubation periods was more influenced by the fibre content and its composition. This resulted in the highest DM disappearance from the $\mathrm{H}$ silages. The above discussed effect of starch content on

TABLE 2

In vivo DM digestibility, in situ DM degradability, in vitro true digestibility (IVTD) and gas production profile of oat and triticale silages

\begin{tabular}{|c|c|c|c|c|c|c|c|c|}
\hline \multirow{2}{*}{ Stage of maturity ${ }^{1}$} & \multicolumn{3}{|c|}{ Oat } & \multirow{2}{*}{ SE } & \multicolumn{3}{|c|}{ Triticale } & \multirow{2}{*}{$\mathrm{SE}$} \\
\hline & $\mathrm{H}$ & M & $\mathrm{MD}$ & & $\mathrm{H}$ & M & $\mathrm{MD}$ & \\
\hline \multicolumn{9}{|l|}{ In vivo method } \\
\hline DM digestibility & $66.5^{\mathrm{a}}$ & $56.3^{b}$ & $56.1^{b}$ & 1.61 & $70.5^{a}$ & $62.8^{\mathrm{ab}}$ & $58.3^{b}$ & 2.07 \\
\hline \multicolumn{9}{|l|}{ In situ method } \\
\hline $0 \mathrm{~h}$ & $35.2^{\mathrm{c}}$ & $41.2^{\mathrm{b}}$ & $44.2^{\mathrm{a}}$ & 0.35 & $34.0^{\mathrm{h}}$ & $39.0^{a}$ & $38.7^{a}$ & 0.41 \\
\hline $2 \mathrm{~h}$ & $41.3^{c}$ & $43.7^{b}$ & $45.6^{a}$ & 0.39 & $36.9^{b}$ & $40.0^{\circ}$ & $39.4^{3}$ & 0.50 \\
\hline $4 \mathrm{~h}$ & $42.6^{\mathrm{b}}$ & $44.5^{\mathrm{a}}$ & $45.9^{a}$ & 0.43 & $39.6^{\mathrm{B}}$ & $40.7^{a}$ & $39.7^{\mathrm{a}}$ & 0.55 \\
\hline $8 \mathrm{~h}$ & $50.7^{\mathrm{a}}$ & $47.2^{b}$ & $49.5^{\mathrm{ab}}$ & 0.69 & $47.4^{\mathrm{a}}$ & $43.7^{b}$ & $41.5^{c}$ & 0.46 \\
\hline $16 \mathrm{~h}$ & $58.7^{\mathrm{a}}$ & $52.3^{\mathrm{b}}$ & $53.3^{\mathrm{b}}$ & 0.98 & $53.5^{\mathrm{a}}$ & $48.9^{b}$ & $45.1^{\mathrm{c}}$ & 0.83 \\
\hline $24 \mathrm{~h}$ & $66.9^{a}$ & $57.8^{\mathrm{b}}$ & $59.2^{\mathrm{b}}$ & 0.91 & $66.5^{\mathrm{a}}$ & $56.2^{b}$ & $57.9^{\mathrm{b}}$ & 1.04 \\
\hline $48 \mathrm{~h}$ & $76.6^{\mathrm{a}}$ & $66.3^{b}$ & $66.9^{b}$ & 0.97 & $75.8^{\mathrm{a}}$ & $64.4^{b}$ & $66.1^{\mathrm{b}}$ & 1.11 \\
\hline $72 \mathrm{~h}$ & $80.3^{a}$ & $69.4^{\mathrm{b}}$ & $69.1^{\mathrm{b}}$ & 0.56 & $79.7^{a}$ & $67.9^{\mathrm{b}}$ & $66.0^{\mathrm{h}}$ & 0.71 \\
\hline A & $36.5^{c}$ & $4 ! .4^{b}$ & $44.6^{4}$ & 0.66 & $34.6^{c}$ & $39.6^{b}$ & $41.3^{a}$ & 0.57 \\
\hline B & $45.4^{a}$ & $35.9^{h}$ & $30.7^{\mathrm{c}}$ & 1.36 & $49.3^{a}$ & $33.4^{\circ}$ & $33.5^{\mathrm{b}}$ & 1.48 \\
\hline C & $0.046^{a}$ & $0.028^{b}$ & $0.027^{b}$ & 0.00 & $0.042^{\mathrm{a}}$ & $0.028^{b}$ & $0.028^{b}$ & 0.00 \\
\hline $\mathrm{ERD}^{2}$ & $56.2^{\mathrm{a}}$ & $51.4^{c}$ & $53.1^{b}$ & 0.45 & $54.6^{\mathrm{a}}$ & $50.3^{\mathrm{c}}$ & $52.0^{\mathrm{b}}$ & 0.43 \\
\hline
\end{tabular}

In vitro method

$\begin{array}{lllllllll}\text { IVTD } 8 \mathrm{~h} & 49.2^{\mathrm{a}} & 45.5^{\mathrm{b}} & 47.2^{\mathrm{ab}} & 0.64 & 47.3^{\mathrm{a}} & 43.4^{\mathrm{a}} & 44.1^{\mathrm{a}} & 0.95 \\ \text { IVTD 24h } & 69.6^{\mathrm{a}} & 60.0^{\mathrm{b}} & 61.9^{\mathrm{b}} & 1.5 \mathrm{~A} & 63.8^{\mathrm{a}} & 59.3^{\mathrm{a}} & 60.2^{\mathrm{a}} & 1.02 \\ \text { IVTD } 48 \mathrm{~h} & 64.1^{\mathrm{a}} & 61.2^{\mathrm{a}} & 62.7^{\mathrm{a}} & 0.78 & 68.3^{\mathrm{a}} & 62.9^{\mathrm{b}} & 61.8^{\mathrm{b}} & 1.12\end{array}$

Gas production technique

\begin{tabular}{|c|c|c|c|c|c|c|c|c|}
\hline TGP, ml $100 \mathrm{mg}^{-1} \mathrm{DM}$ & $12.57^{\circ}$ & $14.33^{b}$ & $16.19^{\mathrm{a}}$ & 0.19 & $17.57^{\mathrm{a}}$ & $15.59^{\mathrm{h}}$ & $17.97^{\mathrm{a}}$ & 0.22 \\
\hline GP rate constant, $\mathrm{ml} \mathrm{h}^{-1}$ & $0.07^{\circ}$ & $0.13^{\mathrm{b}}$ & $0.14^{\mathrm{a}}$ & 0.001 & $0.09^{\mathrm{b}}$ & $0.10^{\mathrm{a}}$ & $0.11^{\mathrm{a}}$ & 0.002 \\
\hline
\end{tabular}

abe - means with the same letter are not significantly different $(\mathrm{P}>0.05)$

$1 \mathrm{H}$ - heading; $\mathrm{M}$ - milk stage; MD - milk-dough stage

2 effective rumen degradability of DM 
TABLE 3

Some correlation coefficients between starch and NDF contents and digestibility parameters determined by different methods

\begin{tabular}{lccc}
\hline & Starch & NDF & In vivo DM digestibility \\
\hline ERD' $^{\prime}$ & -0.67 & -0.56 & 0.34 \\
Fraction - A & $0.92^{* *}$ & -0.15 & $-0.94^{* *}$ \\
Fraction - B & $-0.90^{*}$ & -0.03 & $0.96^{* *}$ \\
Rate constant - C & $-0.9]^{*}$ & -0.34 & 0.68 \\
IVTD 24 h & -0.72 & & 0.60 \\
IVTD 48 h & -0.81 & -0.64 & $0.89^{*}$ \\
TGP & 0.35 & 0.10 & -0.03 \\
GP rate constant & $0.82^{*}$ & 0.34 & $-0.86^{*}$ \\
In vivo DM digestibility & $-0.93^{* *}$ & 0.00 & \\
\hline
\end{tabular}

${ }^{*} \mathrm{P}<0.05,{ }^{* * \mathrm{P}<0.01}$

'effective rumen degradability of DM

rumen DM degradability may be confirmed by the high and significant relationship between starch content and the in situ constants (A, B and C; Table 3). Starch content was positively correlated with the $\mathrm{A}$ fraction and negatively with the $\mathrm{B}$ fraction.

Irrespective of the time of incubation, the highest IVTD was obtained for silages made at heading stage (Table 2). Prolonging plant maturity from $\mathrm{M}$ to $\mathrm{MD}$ stage had no effect on IVTD at any incubation time. There was no correlation between IVTD (at any incubation periods) and NDF content in silages (Table 3). On the other hand, there was a relationship between IVTD and starch content, which was however significant only for IVTD $48 \mathrm{~h}$. The lack of significant differences (statistical analysis not shown) between IVTD obtained after 24 and $48 \mathrm{~h}$ of incubation shows that this part of organic mattcr, which determines the differences between plants and stages of maturity, likely undergoes very fast fermentation processes (within $24 \mathrm{~h}$ ).

The total gas production (TGP) as well as the GP rate constant pointed to the silages made of plants cut at MD stage as the most susceptible to rumen fermentation, especially in the case of oat (Table 2). It is difficult to explain why the $\mathrm{H}$ stage triticale silage TGP was as high as in the MD silage. There was no relationship between TGP and starch or NDF contents in the samples (Table 3). The results of the volume of gas produced should be interpreted with care, particularly when feedstuffs with a high content of starch are studied (Menke and Steingass, 1988). The fermentation of casily fermented sugars leads to the production of high amounts 
of propionic acids by rumen microflora. This process influences the volume of gases produced to a lesser extent than the production of acetic and butyric acids (lack of $\mathrm{CO}_{2}$ and then $\mathrm{CH}_{4}$ separation) (Williams, 2000).

Irrespective of the plant species, its aging significantly increased the GP rate constant. Moreover, a significant relationship ( $\mathrm{r}=0.82)$ was found between starch content and GP rate constant (Table 3 ). This means that if the sample contains more starch, as a result of aging of the plant, the rate of gas production increases.

The reason for the opposite signs of the correlation coefficients between starch content and rate constant C (minus; in situ method) and GP rate constant (plus) is probably in the nature of the method studied. In the in situ method the rate constant is calculated considering the disappearance of the sample from the bag. If the starch disappears after times of incubation, the rate constant $\mathrm{C}$ of fraction $\mathrm{B}$ is influenced by the non-starch components. In the GP technique, the products of the starch fermentation remain in the sample and the GP rate constant shows the rate of gas production of the whole material, including such products. Also Valentin et al. (1999), who studied maize silage DM digestibility determined by different methods, concluded that the in situ nylon bag method and GP technique did not give the same prediction of nutritive value of samples.

\section{General considerations}

The results obtained in this study confirm the well-known fact that along with advancing maturity of cereal plants, the starch content increases (in DM) and at the same time the fibre content (and its fractions) remains more or less stable. This may have a significant effect on digestibility, regardless of the method used. In all of the methods under comparison, the highest digestibility coefficients were shown for $\mathrm{H}$ silages. Based on a classical understanding of the process of lignification of plants, one could assume that prolongation of plant vegetation until the MD stage of growth could constantly decrease its digestibility. However, increasing the content of starch in MD silages, in relation to $\mathrm{M}$ and $\mathrm{H}$ silages, may mask the effect of lignification. Due to this process, regardless of digestibility method, the silages made at MD stage of growth had equal or even higher digestibility when compared with $\mathrm{M}$ silages. In this context, it can be assumed that the level of lignification influences DM digestibility only in early stages of growth, whereas for later stages, the starch content seems to be the most important factor. The above tendencies might have been confirmed by the correlation coefficients between starch and NDF contents and digestibility parameters (Table 3 ). None of the coefficients between NDF and digestibility were significant.

Assuming in vivo DM digestibility as a point of reference, the highest relationship between in vivo and in situ or in vitro digestibility was observed for degradability parameters (A and B) of the in situ method (Table 3). Additionally, statisti- 
cally proved correlations were also observed for IVTD $48 \mathrm{~h}$ and GP rate constant. Other parameters such as IVTD $24 \mathrm{~h}$ or ERD were not correlated with in vivo DM digestibility. It was particularly a surprise in the case of TGP and ERD, considering the high correlation with fractions $\mathrm{A}$ and $\mathrm{B}$. Due to the number of observations, the results of such a comparison should be taken with caution. However, also Adesogan et al. (1998) showed an imprecise prediction of in vivo digestibility from chemical composition (starch included) as well as from in vitro digestibility of whole crop wheat silage when determined by different methods. It is possible that the changing nature of the samples caused by advancing maturity (from fibrous to starchy) could bias some in vitro analyses, for example the gas production technique.

\section{CONCLUSIONS}

Aging of whole oats or triticale crops changed the chemical composition of whole crop silages. The main effect was an increasing content of starch. Prolonging growth increased lignification of the plants only from heading to milk stage of maturity. The starch content had a greater effect than NDF on in vivo, in situ and in vitro digestibility. In vivo DM digestibility was significantly correlated with rumen DM degradability parameters (A and B) of the in situ method, IVTD $48 \mathrm{~h}$ and $\mathrm{GP}$ rate constant.

\section{ACKNOWLEDGEMENT}

The authors wish to thank Mr. J.J. Lee (UBC, Canada) for analytical aid and the staff of the Laboratory of the Department of Animal Nutrition (Cracow Agricultural University, Poland) for chemical analyses.

\section{REFERENCES}

Adesogan A.T., Owen E., Givens D.I., 1998. Prediction of the in vivo digestibility of whole-crop wheat from in vitro digestibility, chemical composition, in situ rumen degradability, in vitro gas production and near infrared reflectance spectroscopy. Anim. Feed Sci. Tech. 74, 259-272

AOAC, 1995. Official Methods of Analysis. Association of Official Analytical Chemists. $16^{\text {th }}$ Edition. Arlington, VA

Beuvink J.M.W., Kogut J., 1993. Modeling gas production kinetics of grass silages incubated with buffered ruminal fluid. J. Anim. Sci. 71, 1041-1046

Borowiec F., Furgał K., Kamiński J., Zając T., 1998. Nutritional value of silage made of whole plant barley harvested at various grain ripeness stages. J. Anim. Feed. Sci. 7, 45-54 
Cernau P., Michalet-Doreau B., 1991. In situ starch degradation of different feeds in the rumen. Reprod. Nutr. Develop. 31, 65-72

Deriaz R. E., 1961. The routine analysis of carbohydrates and lignin in herbage. J. Sci. Food Agr. 12, $152-160$

Deaville E.R., Owen E., Adesogan A.T., Rymer C., Huntington J.A., Lawrence T.L.J. (Editors), 1998. In vitro techniques for measuring nutrient supply to ruminants. Proceedings of International Symposium, Brit. Soc. Anim. Sci., Amer. Soc. Anim. Sci. and Europ. Assoc. Anim. Production, Reading (UK). Occasional Publication, Brit. Soc. Anim. Sci. 22., BSAS, Edinburgh

Dewar W.A., McDonald P., 1961. Determination of dry matter in silage by distillation with toluene. J. Sci. Food Agr. 12, 790-795

Faisant N., Planchot V., Kozlowski F., Pacouret Mp., Colonna P., Champ M., 1995. Resistant starch determination adapted to products containing high level of resistant starch. Sci. Alim. 15, 83-89

Goering H.K., Van Soest P.J., 1970. Forage Fiber Analysys (Apparatus, Reagents, Procedures, and Some Applications). Agric. Handbook No. 379. ARS-USDA. Washington, DC

Jones D.I.H., Theodoru M.K., 2000. Enzyme techniques for estimating digestibility. In: D.J. Givens, E. Owen, R.F.E. Axford, H.M. Omed (Editors). Forage Evaluation in Ruminant Nutrition. CABI Publishing, New York, pp. 155-175

Mannerkorpi P., Brandt M., 1995. Feeding value of barley plants as related to stage of maturity. 2. In vivo digestibility and voluntary intake of silages. Acta Agr. Scand., Sect. A., Anim. Sci. 45, 153-158

Menke, K.H, Raab L., Salewski A., Steingass H., Fritz D., Schneider W., 1979. The estimation of the digestibility and metabolizable energy content of ruminant feedstuffs from the gas production when they are incubated with rumen liquor. J. Agr. Sci. 93, 218-222

Menke K.H., Steingass H., 1988. Estimation of the energetic feed value obtained from chemical analysis and in-vitro gas production using rumen fluid. Anim. Res. Develop. 28, 7-12

Micek P., Borowiec F., Kowalski Z.M., 2001. Digestion of whole-crop grain silage starch in ruminants. J. Anim. Feed Sci. 10, Suppl. 2, 49-55

Michalet-Doreau B., Verité R., Chapoutot P., 1987. Methodologie de mesure de la degradabilite in sacco de l'azote des aliments dans le rumen. Bull. Tech. C.R.Z.V. Theix. 69, 5-7

Mills J.A.N., France J., Dijkstra J., 1999. A review of starch digestion in the lacting dairy cow and proposals for a mechanistic model: 1. Dietary starch characterisation and ruminal starch digestion. J. Anim. Feed Sci. 8, 291-340

Opatpatanakit Y., Kellaway R.C., Leon I.J., Annison G., Kirby A., 1994. Microbial fermentation of cereal grains in vitro. Aust. J. Agr. Res. 45, 1247-1263

Ørskov E.R., McDonald P., 1979. The estimation of protein degradability in the rumen from incubation measurements weighted according to rates of passage. J. Agr. Sci. 92, 499-503

Pell, A.N., Schofield P., 1993. Computerized monitoring of gas production to measure forage digestion in vitro. J. Dairy Sci. 76, 1063-1073

SAS, 1995: SAS/STAT Users Guide (Release 6,03). SAS Inst. Inc. Cary, NC

Schoficld P., Pell A.N., 1995. Validity of using accumulated gas pressure readings to measure forage digestion in vitro: A comparison involving three forages. J. Dairy Sci. 78, 2230-2238.

Stern M.P., Bach A., Calsamiglia S., 1997. Alternative techniques for measuring nutrient digestion in ruminants. J. Anim. Sci. 7, 2256-2276

Valentin F., Williams P.E.V., Forbes J.M. Sauvant D., 1999. Comparison of the in vitro gas production technique and the nylon bag degradability technique to measure short- and long-term processes of degradation of maize silage in dairy cows. Anim. Feed Sci. Tech. 78, 81-99

Van Soest P.J., 1994. Nutritional Ecology of the Ruminant. $2^{\text {nd }}$ Edition. Comstock Publishing Associates, Division of Cornell University Press, Ithaca, London 
Van Soest P.J., Wine R.H., Moore L.A., 1966. Estimation of the true digestibility of forages by the in vitro digestion of cell walls. In: Procedings of Xth International Grassland Congress, Helsinki, pp. 438-441

Williams B.A., 2000. Cumulative gas-production techniques for forage evoluation. In: D.J. Givens, E. Owen, R.F.E. Axford, H.M. Omed (Editors). Forage Evaluation in Ruminant Nutrition. CABI Publishing, New York, pp. 189-215

Wilman D., Adesogan A., 2000. A comparison of filter bag methods with conventional tube methods of determining the in vitro digestibility of forages. Anim. Feed Sci. Tech. 84, 33-47

\section{STRESZCZENIE}

\section{Strawność kiszonek sporządzonych z calych roślin zbożowych oznaczona różnymi metodami}

Materiałem do badań były kiszonki z owsa (Avena sativa, odm. Senator) oraz pszenżyła (odm. Bogo) zebrane w trzech fazach rozwojowych: kloszenje (H), dojrzałość mleczna (M) i mlecznowoskowa ziarna (MD), różniące się zawartością skrobi. Strawność oznaczono metodami: woreczków nylonowych in situ, strawność rzeczywistą in vitro (IVTD) oraz in vitro półautonatyczną techniką gazową (GP). Dodatkowo oznaczono strawność in vivo kiszonek w całym przewodzie pokarmowym tryczków. Zawartość skrobi ( $\mathrm{g} \mathrm{kg}^{-1} \mathrm{~s} . \mathrm{m}$.) w kiszonkach z owsa wynosiła: $13(\mathrm{H}), 110$ (M) i 130 (MD), a w kiszonkach z pszenżyta odpowiednio 7, 78 i 147. Zawartość NDF ( $\mathrm{g} \mathrm{kg}^{-1} \mathrm{~s} . \mathrm{m}$.) w tych kiszonkach wynosila odpowiednio 471, 506 i 483 oraz 517, 551 i 499.

Strawność s.m. in vivo kiszonck sporządzonych z materiału zebranego w fazie kloszenia była najwyższa oraz najwyższy był efektywny rozkład suchej masy w żwaczu (ERD), oznaczony metodą in situ. Strawność in vivo s.m. byla statystycznic istotnic skorelowana z zawartością skrobi w kiszonkach. Nie wykazano jednak istotnej zależności pomiędzy ERD a zawartością skrobi lub NDF. $\mathrm{Z}$ drugiej strony zawartość skrobi była istotnie skorclowana z wicikością stałych rozkładu s.m., $\mathrm{tj}$. A, $\mathrm{B}$ i C $(r>0.90 ; \mathrm{P}<0.05)$. Bez względu na gatunek rośliny, IVTD kiszonek sporządzonycl z materiału zebranego w fazie dojrzałości mleczncj i mleczno-woskowej ziarna była wyźsza niż kiszonki zebranej $w$ fazie kłoszenia. Wykazano przy tym istotną zależność pomiędzy IVTD $48 \mathrm{~h}$ a zawartością skrobi. Całkowita ilość produkowanego gazu (TGP), jak również stała prođukcji gazu wskazują, żc najbardziej podatne na fermentację są kiszonki zebrane w fazie MD, zwlaszcza owies. Nie wykazano jednak istotnej zależności pomiędzy TGP a zawartością skrobi lub NDF. Z drugiej jednak strony wykazano istotną korelację $(\mathrm{P}<0.05)$ pomiędzy zawartością skrobi i stałą produkcją gazu.

Spośród porównywanych metod oznaczania strawności, strawność s.m. in vivo była najwyżcj skorelowana z wiclkością frakcji A i C (metoda in situ), IVTD 48 h oraz z wielkością stałej produkcji gazu. 